\title{
The study of phenolic compounds and the antimicrobial action of the alcoholic extract from the cake of the red raspberry fruit
}

Aim. To study the antimicrobial action and the quantitative content of phenolic compounds of the alcoholic extract from the cake of the red raspberry fruit (Rubus idaeus).

Materials and methods. The object of the study was the extract obtained from the fruit of Rubus idaeus. The content of phenolic compounds was determined by the spectrophotometric method. The study of the antibacterial activity of the extracts was carried out by the agar diffusion method.

Results and discussion. It has been found that the content of hydroxycinnamic acid derivatives is $2.21 \pm 0.02 \%$, flavonoids $-0.82 \pm 0.01 \%$, and the amount of phenolic compounds is $4.52 \pm 0.02 \%$ in the extract of the red raspberry fruit. The results of the studies conducted have shown that the test sample of the extract from the raspberry fruit has a wide range of the antimicrobial activity, including the antibacterial and antifungal activity.

Conclusions. By studying the antimicrobial activity the possibility of creating a new antimicrobial drug based on the raspberry fruit has been proven. The content of phenolic compounds in the extract from the cake of the red raspberry fruit has been studied.

Key words: red raspberry; phenolic compounds; extract; antimicrobial activity

\section{І. М. Поліщук, О. М. Кошовий, Т. П. Осолодченко, М. А. Комісаренко}

\section{Дослідження фенольних сполук та антимікробної дії спиртового екстракту} зі жмиху плодів малини звичайної

Мета. Метою даної роботи стало дослідження кількісного вмісту фенольних сполук етанольного екстракту жмиху плодів малини звичайної та його антимікробної дії.

Матеріали та методи. Об'єктами дослідження був екстракт, отриманий зі жмиху плодів R. Idaeus. Вміст френольних сполук визначали спектрофотометричним методом. Вивчення антибактеріальної активності екстрактів проводили методом дифузії в агар.

Результати та їх обговорення. Встановлено вміст похідних гідроксикоричної кислоти 2,21 \pm 0,02 \%, фрлавоноїдів 0,82 \pm 0,01 \% та суми фенольних сполук 4,52 \pm 0,02 \% в екстракті плодів малини звичайної. Результати проведених досліджень показали, що досліджуваний зразок екстракту з плодів малини має широкий спектр антимікробної активності, включаючи антибактеріальну і протигрибкову.

Висновки. Шляхом вивчення антимікробної активності доведена можливість створення нового лікарського засобу антимікробної дії на основі плодів малини. Досліджено вміст фенольних сполук у екстракті зі жмиху плодів малини звичайної

Ключеві слова: малина звичайна; френольні сполуки; екстракт; антимікробна дія

\section{И. Н. Полищук, О. Н. Кошевой, Т. П. Осолодченко, Н. А. Комиссаренко}

\section{Исследование фенольных соединений и антимикробного действия спиртового экстракта из жмыха плодов малины обыкновенной}

Цель. Целью данной работы было исследование противомикробного действия и количественного содержания френольных соединений этанольного экстракта жмыха плодов малины обыкновенной.

Материалы и методы. Объектами исследования был экстракт, полученный из плодов R. Idaeus. Содержание фенольных соединений определяли спектрофотометрическим методом. Изучение антибактериальной активности экстрактов проводили методом дифффузии в агар.

Результаты и их обсуждение. Установлено содержание производных гидроксикоричной кислоты 2,21 \pm 0,02 \%, фрлавоноидов 0,82 \pm 0,01 \% и суммы фенольных соединений 4,52 \pm 0,02 \% в экстракте плодов малины обыкновенной. Результаты проведенных исследований показали, что исследуемый образец экстракта из плодов малины имеет широкий спектр антимикробной активности, включая антибактериальную и противогрибковую.

Выводы. Путем изучения антимикробной активности доказана возможность создания нового антимикробного лекарственного средства на основе плодов малины. Исследовано содержание фенольных соединений в экстракте плодов малины обыкновенной.

Ключевые слова: малина обыкновенная; фенольные соединения; экстракт; антимикробная активность 
Medicinal products based on the medicinal plant raw material have an effective impact on the body, usually have low toxicity, are not xenobiotics and are increasingly used in medical practice. Medicinal plants are the source of more than a third of all medicines. The expansion of the range of herbal medicinal products, increase of the requirements for the quality of medicines based on the plant raw material require new approaches to the analysis, standardization and the comprehensive study of medicinal plants. Because of the limited reserves and the unfavorable environmental situation a special attention when developing new herbal medicines is paid to medicinal plants of domestic flora, which are widely cultivated.

Red raspberry (Rubus idaeus L., family Rosaceae) is one of these plants. Raspberry fruits have long been used in various areas of the national economy, such as medicine, pharmaceutical and food industries, etc. In officinal medicine raspberry fruit is used as a diaphoretic, antipyretic agent. According to the literature data raspberry has a rich chemical composition. Phenolic compounds that exhibit the antimicrobial action are the most important, they make raspberry a valuable source of biologically active substances (BAS) and promising medicinal plant raw material for use in medicine and pharmacy $[1,2,3,4]$.

The aim of the work was to study the quantitative content of phenolic compounds of the alcoholic extract from the cake of the red raspberry fruit and its antimicrobial action.

\section{Materials and methods}

The object of the study was the extract obtained from the cake of the fruit of Rubus idaeus collected in the places of its cultivation. The material was collected in 2017 during the fruiting period in the vicinity of the village of Ternova, Kharkiv region. The juice was squeezed from the fruit; then the resulting cake was dried and poured with $80 \%$ alcohol in the ratio of $1: 5$ taking into account the absorption coefficient.

The content of phenolic compounds was determined by the spectrophotometric method calculated with reference to gallic acid. The absorption maxima of gallic acid are at 214 and $270 \mathrm{~nm}$. The measurements are advisable at $270 \mathrm{~nm}$ since at this wavelength the effect of related substances on the measurement results is less.

The amount of phenolic compounds calculated with reference to rutin was determined by the spectrophotometric method after formation of the complex with $\mathrm{AlCl}_{3}$ at $417 \mathrm{~nm}[5,6]$.

The content of hydroxycinnamic acid derivatives was determined by the spectrophotometric method calculated with reference to chlorogenic acid since it is dominant among hydroxycinnamic acids. The absorption maximum of chlorogenic acid is $\chi=327 \mathrm{~nm}$; therefore, the measurements were carried out at this wavelength $[5,6]$.

The results of the study of the content of phenolic compounds are given in Tab. 1. The study of the antibacterial activity of the extracts was carried out by the agar diffusion method in the Laboratory of Biochemistry and Biotechnology, Mechnikov Institute of Microbio- logy and Immunology of the NAMS of Ukraine under the supervision of Candidate of Biology (Ph.D.) T. P. Osolodchenko.

The microbial suspension of strains (microorganisms) was prepared using a Densi-La-Meter device (manufactured by PLIVA-Lachema, Czech Republic; the wavelength $-540 \mathrm{~nm}$ ). The microbial suspension of strains was prepared according to the instruction included to the device, and the information letter on innovations in the healthcare system No. 163-2006 "Standardization of preparation of microbial suspensions" (Kyiv). The cultures of strains were synchronized using the low temperature $\left(4{ }^{\circ} \mathrm{C}\right)$. The microbial load was $10^{7}$ microbial cells per $1 \mathrm{ml}$ of the medium and was determined according to the McFarland standard. The 18-24-hour culture of strains of microorganisms was used. For our studies the Mueller-Hinton agar (manufactured by "HIMediaLaboratories Pvt. Ltd”, India”, expiry date: XII.2018) was used. For Candida albicans the Sabouraud agar (manufactured by "HIMediaLaboratories Pvt. Ltd", India", expiry date: XII.2018) was used.

The method of drug diffusion in agar was performed by wells. Determination of the activity of antibacterial drugs was carried out on two layers of a dense nutrient medium poured into Petri dishes. In the lower layer the starvation uncultivated media (agar-agar, water, salts) were used. The lower layer was a substrate of $10 \mathrm{ml}$ of the starvation agar, on which 3-6 thin-walled stainless steel cylinder with the diameter of $8 \mathrm{~mm}$ and the height of $10 \mathrm{~mm}$ were mounted strictly horizontally. Around the cylinders the upper layer consisting of the agar nutrient medium molten and cooled to $40{ }^{\circ} \mathrm{C}$ was poured; in this medium the corresponding standard of the daily culture of test strains was introduced. In advance, the upper layer was well mixed to form a homogeneous mass. After hardening the cylinders were pulled out with sterile tweezers, and the drugs studied were placed into the wells formed. To compare the results the reference drug - Chlorophyllipt spray manufactured by the State Scientific Center of Drugs (DNCLZ) and the samples of the antibacterial and antifungal agent from raspberry $(0.3 \mathrm{ml})$ were taken.

Table 1

The quantitative content of phenolic compounds of the extract from the cake of the raspberry fruit

\begin{tabular}{|l|c|}
\hline \multicolumn{1}{|c|}{$\begin{array}{c}\text { The group of BAS, } \\
\text { research method }\end{array}$} & $\begin{array}{c}\text { The quantitative } \\
\text { content, } \%\end{array}$ \\
\hline \multicolumn{2}{|c|}{ Derivatives of hydroxycinnamic acid: } \\
\hline $\begin{array}{l}\text { The spectrophotometric } \\
\text { method calculated with } \\
\text { reference to chlorogenic acid }\end{array}$ & $2.21 \pm 0.02$ \\
\hline \multicolumn{2}{|c|}{ Flavonoids: } \\
\hline $\begin{array}{l}\text { The spectrophotometric } \\
\text { method calculated with } \\
\text { reference to rutin }\end{array}$ & $0.82 \pm 0.01$ \\
\hline \multicolumn{2}{|c|}{ The amount of phenolic compounds: } \\
\hline $\begin{array}{l}\text { The spectrophotometric } \\
\text { method calculated with } \\
\text { reference to gallic acid }\end{array}$ & $4.52 \pm 0.02$ \\
\hline
\end{tabular}


The antimicrobial and antifungal activity of raspberry fruit extract and the reference drug in relation to museum strains

\begin{tabular}{|l|c|c|c|c|c|c|}
\hline \multirow{2}{*}{ Medicines } & \multicolumn{5}{|c|}{ Diameters of the growth inhibition zones, mm, the number of test repetitions $\mathrm{n}=3$} \\
\cline { 2 - 7 } & $\begin{array}{c}\text { Staphylococcus } \\
\text { aureus } \\
\text { ATCC 25923 }\end{array}$ & $\begin{array}{c}\text { Escherichia coli } \\
\text { ATCC 25922 }\end{array}$ & $\begin{array}{c}\text { Proteus vulgaris } \\
\text { ATCC 4636 }\end{array}$ & $\begin{array}{c}\text { Pseudomonas } \\
\text { aeruginosa } \\
\text { ATCC 27853 }\end{array}$ & $\begin{array}{c}\text { Basillus subtilis } \\
\text { ATCC 6633 }\end{array}$ & $\begin{array}{c}\text { Candida } \\
\text { albicans } \\
\text { ATCC 653/885 }\end{array}$ \\
\hline $\begin{array}{l}\text { Extract from } \\
\text { the raspberry } \\
\text { fruit }\end{array}$ & $36,36,35$ & $38,39,40$ & $34,35,35$ & $35,35,35$ & $40,40,42$ & $37,36,36$ \\
\hline $\begin{array}{l}\text { Chlorophyllipt } \\
\text { (DNCLZ) }\end{array}$ & $15,14,14$ & $15,14,14$ & growth & growth & $15,14,14$ & growth \\
\hline
\end{tabular}

The antimicrobial and antifungal activity of raspberry fruit extract by the method of serial dilution in relation to museum strains

\begin{tabular}{|l|c|c|c|c|c|c|}
\hline \multirow{2}{*}{ Medicine } & \multicolumn{6}{|c|}{ Dilution } \\
\cline { 2 - 7 } & $\begin{array}{c}\text { Staphylococcus } \\
\text { aureus } \\
\text { ATCC 25923 }\end{array}$ & $\begin{array}{c}\text { Escherichia coli } \\
\text { ATCC 25922 }\end{array}$ & $\begin{array}{c}\text { Proteus vulgaris } \\
\text { ATCC 4636 }\end{array}$ & $\begin{array}{c}\text { Pseudomonas } \\
\text { aeruginosa } \\
\text { ATCC 27853 }\end{array}$ & $\begin{array}{c}\text { Basillus subtilis } \\
\text { ATCC 6633 }\end{array}$ & $\begin{array}{c}\text { Candida } \\
\text { aibicans } \\
\text { ATCC 653/885 }\end{array}$ \\
\hline $\begin{array}{l}\text { Extract from } \\
\text { the raspberry } \\
\text { fruit }\end{array}$ & $1: 32$ & $1: 32$ & $1: 16$ & $1: 16$ & $1: 32$ & $1: 16$ \\
\hline
\end{tabular}

The volume of the medium for the upper layer ranged from 14 to $16 \mathrm{ml}$. The dishes were dried for 30-40 min at room temperature and placed in a thermostat for $18-24 \mathrm{~h}$.

When assessing the antimicrobial and antifungal properties of drugs the following criteria were used:

- the absence of the growth inhibition zones of strains around the well, as well as the inhibition zones less than $10 \mathrm{~mm}$ indicates that the strains are insensitive to the drug of the local action introduced into the well; - the growth inhibition zones with the diameter of 10$15 \mathrm{~mm}$ shows a low sensitivity of strains to the drug of the local action;

- the growth inhibition zones with the diameter of $15-25 \mathrm{~mm}$ is regarded as an indicator of the sensitivity of strains to the drug of the local action;

- the growth inhibition zones, which diameter exceeds

$25 \mathrm{~mm}$, indicates a high sensitivity of strains to the drug of the local action.

When studying of the antimicrobial and antifungal properties of medicines the following museum strains:
Staphylococcus aureus ATCC 25923, Escherichia coli ATCC 25922, Proteus vulgaris ATCC 4636, Pseudomonas aeruginosa ATCC 27853, Basillus subtilis, ATCC 6633, Candida albicans ATCC 653/885; and such clinical strains as Staphylococcus aureus 44, Escherichia coli 17, Proteus vulgaris 16, Pseudomonas aeruginosa 39, Pseudomonas aeruginosa 68, Candida albicans 46 were used.

To obtain reliable data for the conclusion about the effectiveness of drugs three independent tests (the number of repetitions) were performed. The data of tests of the antibacterial and antifungal activity are presented in Tab. 2-5.

\section{Results and discussion}

It has been found that the content of hydroxycinnamic acid derivatives is $2.21 \pm 0.02 \%$, flavonoids $0.82 \pm 0.01 \%$, and the amount of phenolic compounds is $4.52 \pm 0.02 \%$ in the extract of the red raspberry fruit.

The results of the studies conducted have shown that the test sample of the extract from the raspberry fruit has a wide range of the antimicrobial activity, including the

Table 4

The antimicrobial and antifungal activity of raspberry fruit extract and the reference drug in relation to clinical strains

\begin{tabular}{|l|c|c|c|c|c|c|}
\hline \multirow{2}{*}{ Medicines } & \multicolumn{5}{|c|}{ Diameters of the growth inhibition zones, mm, the number of test repetitions $\mathrm{n}=3$} \\
\cline { 2 - 7 } & $\begin{array}{c}\text { Staphylococcus } \\
\text { aureus 44 }\end{array}$ & $\begin{array}{c}\text { Escherichia coli } \\
17\end{array}$ & $\begin{array}{c}\text { Proteus vulgaris } \\
16\end{array}$ & $\begin{array}{c}\text { Pseudomonas } \\
\text { aeruginosa } 39\end{array}$ & $\begin{array}{c}\text { Pseudomonas } \\
\text { aeruginosa } 68\end{array}$ & $\begin{array}{c}\text { Candida } \\
\text { albicans } 46\end{array}$ \\
\hline $\begin{array}{l}\text { Extract from } \\
\text { the raspberry } \\
\text { fruit }\end{array}$ & $30,30,30$ & $31,29,29$ & $27,27,27$ & $26,25,26$ & $31,31,32$ & $26,27,26$ \\
\hline $\begin{array}{l}\text { Chlorophyllipt } \\
\text { (DNCLZ) }\end{array}$ & $11,12,11$ & $12,11,11$ & growth & growth & 11,11, growth & growth \\
\hline
\end{tabular}


The antimicrobial and antifungal activity of raspberry fruit extract by the method of serial dilution in relation to clinical strains

\begin{tabular}{|c|c|c|c|c|c|c|}
\hline \multirow{2}{*}{ Medicine } & \multicolumn{6}{|c|}{ Dilution } \\
\cline { 2 - 7 } & $\begin{array}{c}\text { Staphylococcus } \\
\text { aureus 44 }\end{array}$ & $\begin{array}{c}\text { Escherichia coli } \\
17\end{array}$ & $\begin{array}{c}\text { Proteus vulgaris } \\
16\end{array}$ & $\begin{array}{c}\text { Pseudomonas } \\
\text { aeruginosa 39 }\end{array}$ & $\begin{array}{c}\text { Pseudomonas } \\
\text { aeruginosa 68 }\end{array}$ & $\begin{array}{c}\text { Candida } \\
\text { albicans 46 }\end{array}$ \\
\hline $\begin{array}{l}\text { Extract from the } \\
\text { raspberry fruit }\end{array}$ & $1: 32$ & $1: 16$ & $1: 16$ & $1: 16$ & $1: 32$ & $1: 8$ \\
\hline
\end{tabular}

antibacterial and antifungal activity. A comparative assessment of the level of the antimicrobial activity of the extract against the test strains studied indicates a more pronounced effect on the cultures of gram-positive bacteria $-S$. aureus (including both museum and clinical strains) and B. Subtilis, as well as gram-negative bacterium $-E$. Coli. Thus, the diameter of the growth inhibition zones of cultures of these bacteria around the wells with the samples of the extract from the raspberry fruit was 30-36 mm for the cultures of S. Aureus, 40-42 mm for the culture of $B$. subtilis with the minimal inhibiting concentrations of $1: 32$, and it was higher compared to the diameters of the growth inhibition zones of cultures of gram-negative bacteria $-P$. aeruginos $a$ and C. albicans fungus, they were $25-37 \mathrm{~mm}$ with the minimal inhibiting concentrations of $1: 8-1: 16$.

\section{CONCLUSIONS}

By studying the antimicrobial activity the possibility of creating a new antimicrobial drug based on the raspberry fruit has been proven. The content of phenolic compounds in the extract from the cake of the red raspberry fruit has been studied.

Conflict of Interests: authors have no conflict of interests to declare.

\section{REFERENCES}

1. ГОСТ 3525-75. Плоды малины. - М., 1975.

2. Аврач, А. С. Биологически активные вещества плодов и водных извлечений малины обыкновенной / А. С. Аврач, Е. В. Сергунова, Я. В. Куксова // Фармация. - 2014. - № 1. - С. 8-10.

3. Растительные ресурсы СССР : цветковые растения, их химический состав, использование; семейство Hydrangeaceae - Haloragaceae. - Ленинград : Наука, 1987. - 326 с.

4. Тараховский, Ю. С. Флавоноиды : биохимия, биофизика, медицина / Ю. С. Тараховский. - Пущино: Synchrobook, $2013 .-310$ c.

5. Дослідження фенольних сполук листя евкаліпта / О. М. Кошовий, А. М. Комісаренко, А. М. Ковальова та ін. // Фармаком. 2005. - № 2/3. - С. 151-161.

6. Розробка метода стандартизації нового лікарського засобу піфламін / А. М. Ковальова, Г. В. Георгієвський, В. М. Ковальов та ін. // Фармаком. - 2002. - № 2. - С. 92-97.

\section{REFERENCES}

1. GOST 3525-75. (1975). Plody maliny.

2. Avrach, A. S., Sergunova, E. V., Kuksova, Ia. V. (2014). Farmatciia, 1, 8-10.

3. Rastitelnye resursy SSSR : tcvetkovye rasteniia, ikh khimicheskii sostav, ispolzovanie ; semeistvo Hydrangeaceae - Haloragaceae. (1987.) St: Petersburg: Nauka, 326.

4. Tarakhovskii, Yu. S. (2013.) Flavonoidy: biokhimiia, biofizika, meditcina. Pushchino: Sunchrobook, 310.

5. Koshovyi, O. M., Komisarenko, A. M., Kovalova, A. M., Maloshtan, L. M., Mudryk, I. M. (2005). Farmakom. 2/3, 151 - 161.

6. Kovalova, A. M., Heorhiievskyi, H. V., Kovalov, V. M., Komisarenko, A. M., Tymchenko, M. M. (2002). Farmakom, 2, 92-97.

\section{Information about authors:}

Polischuk I. M., postgraduate student of the Pharmacognosy Department, National University of Pharmacy.

Koshovyi O. M., Doctor of Pharmacy (Dr. habil.), professor, head of the Pharmacognosy Department, National University of Pharmacy.

E-mail: oleh.koshovyi@gmail.com. ORCID: https://orcid.org/0000-0001-9545-8548

Osolodchenko T. P., Candidate of Biology (Ph.D.), senior researcher, head of the Laboratory of Biochemistry and Biotechnology,

Mechnikov Institute of Microbiology and Immunology of the NAMS of Ukraine. E-mail: imitatyana@mail.ru

Komissarenko M. A., teaching assistant of the Pharmacognosy Department, National University of Pharmacy. E-mail: a0503012358@gmail.com.

ORCID: https://orcid.org/0000-0002-1161-8151

Відомості про авторів:

Поліщук І. М., аспірант кафедри хімії природних сполук, Національний фармацевтичний університет

Кошовий О. М., д-р фарм. наук, професор, завідувач кафедри фармакогнозії, Національний фармацевтичний університет

E-mail: oleh.koshovyi@gmail.com. ORCID: https://orcid.org/0000-0001-9545-8548

Осолодченко Т. П., канд. біол. наук, старший науковий співробітник, зав. лабораторії біохімії та біотехнології,

Державна установа «Інститут мікробіології та імунології імені I. І. Мечникова НАМН України»

Комісаренко М. А., асистент кафедри фармакогнозії, Національний фармацевтичний університет. E-mail: a0503012358@gmail.com.

ORCID: https://orcid.org/0000-0002-1161-8151

Сведения об авторах:

Полищук И. Н., аспирант кафедры химии природных соединений, Национальный фармацевтический университет

Кошевой О. Н., д-р фарм. наук, профессор, заведующий кафедрой фармакогнозии, Национальный фармацевтический университет.

E-mail: oleh.koshovyi@gmail.com. ORCID: https://orcid.org/0000-0001-9545-8548

Осолодченко Т. П., канд. биол. наук, старший научный сотрудник, зав. лабораторией биохимии и биотехнологии, Государственное учреждение

«Институт микробиологии и иммунологии имени И. И. Мечникова НАМН Украины». E-mail: imi_lbb@ukr.net.

Комиссаренко Н. А., ассистент кафедры фармакогнозии, Национальный фармацевтический университет. E-mail: a0503012358@gmail.com.

ORCID:https://orcid.org/0000-0002-1161-8151 